\title{
Recuerdo de José Luis L. Aranguren
}

\author{
CARLOS CASTILLA DEL PINO
}

Dejé de ser católico hacia los catorce o quince años, cuando el catolicismo era socialmente imprescindible. Impregnaba todo el medio social español y, sin contención alguna, se introducía, impertinente, hasta en la privacidad. En España - hablo de los años cuarenta y hasta los sesenta- había que tomar posición respecto del catolicismo y el católico. El socialcatolicismo, el poder católico, era el poder. Un catolicismo nioño, cursi, blando en apariencia, pero despiadado hasta la crueldad llegado el caso (y llegaba a las primeras de cambio). Era difícil no ser católico sin ser militante del anticatolicismo. Había que adoptar necesariamente una posición, porque, por ejemplo, había ejercicios espirituales para todos los estamentos, entre otros el universitario; en el ejército se nos llevaba a misa; en el pueblo, durante las vacaciones, como se era del SEU, se nos obligaba a asistir a misa; las playas, los bailes, el cine, el teatro, las costumbres todas eran las impuestas por el poder católico; luego, en provincias, los ejercicios espirituales organizados por el Colegio Oficial de Médicos, de los que sustraerse era destacarse de manera peligrosa. No había propiamente una religión católica, sino una sociedad civil, de grado o por fuerza, católica. Todos los congresos de Psiquiatría a los que asistía se iniciaban con una misa del Espíritu Santo. Había reuniones de psicoterapcutas católicos (con participación francesa, italiana, belga y austríaca).

Buena parte de las energías de muchos españoles se consumían en la tarea de ser anticatólico. A diferencia del de entonces, el catolicismo de ahora no es el poder, sino un poder $-\mathrm{y}$ en franco declive- Nuestro anticatolicismo era misional, y el infiel, ese católico ortodoxo, dispuesto a silenciar todo lo que el catolicismo tenía de reprobable, dispuesto a entender (disculpar) al católico en sus más hipócritas y repugnantes comportamientos. Impensable el diálogo con el católico de entonces: más temprano que tarde, asomaba la irracionalidad, la cerrazón, y no por el dogma sino por la actitud. La cultura hacía a algún que otro católico presentable, incluso el modo de presentarse como «moderno», pero, por su carácter suntuario, era una forma de mendacidad. Lo inaceptable aun del católico más civilizado no era el dogma, ni la fidelidad a sus creencias, sino la inhibición crítica ante las actitudes sociopolíticas del catolicismo oficial.

Aquel catolicismo al que repudiaba con todas mis fuerzas era el catolicismo español, estrictamente vaticanista. En Francia las cosas podían ser diferentes, cuando menos en amplios sectores. Aquellos volúmenes de Cristianismo y Mundo Moderno, de Moeller; los Etudes Carmelitaines; los libros de Maritain, Bernanos, 
Mauriac, los de Mounier y muchos otros. También en Alemania, los de Scheler, los de Romano Guardini...

De pronto, pero aquí, apareció Catolicismo día tras día, de José Luis López Aranguren. Un libro transparente, un libro culto, moderno, inusual para ser de un católico español. Además, criticaba el catolicismo en su aberrante formalismo, sin dejar de ser el autor un declarado católico. Lo que veíamos en esas páginas era a un católico dispuesto a seguir siéndolo, pero como una opción privada e íntima, que no conllevara ser social e impositivamente católico. Aranguren era religiosamente católico, y la religiosidad, repito, un asunto no ya privado sino íntimo. En él, además, la cultura era la forma de apertura a otros mundos distintos al estrictamente católico. A aquel católico que había tras Catolicismo se le podía escuchar y se le podía leer. Se podía ir con él hasta el límite, que no teníamos derecho a sobrepasar, de su pensar y sentir lo religioso. Si su catolicismo era suyo, también reconocía el carácter de íntimo de la religiosidad (o no religiosidad) de su interlocutor, y era, por parte de él, respetado.

Yo tenía noticia de Aranguren por La Filosofia de Eugenio D'Ors, que había leído, pese a la repulsión que por entonces me inspiraba D'Ors, al que vi a veces vestido de falangista, y siempre opulcnto, siempre solemne. Pero Catolicismo suscitó una reacción tan violenta en los medios católicos más ortodoxos como para que no pudiéramos desatenderlo de ninguna manera. La crítica a este libro por el catolicismo oficial - que lo colocaba en el trance de una presunta heterodoxia- no era por su alejamiento del dogma sino del catolicismo civil. Esa forma católica de ser no era la del católico español, era ejemplarmente negativa, un «escándalo». Un católico español no hacía de su religiosidad algo singularmente propio porque, como forma de la vida pública española, cada católico era algo así como un delegado de la autoridad.

A medida que Aranguren era objeto de sospecha y perdía el respeto de la ortodoxia, se lo prestábamos los agnósticos y, desde luego, los heterodoxos. En cierto sentido, Aranguren vino a ser, en la posguerra, lo que Bergamín en la preguerra: un católico para sí.

Yo conocí a Aranguren a las veinticuatro horas de su expulsión de la Universidad. Había ido demasiado lejos en su reprobación del poder católico... Fui a verle a su casa de Velázquez, con un mensaje de aquel grupo de Córdoba que redactamos Praxis, a mostrarle nuestra adhesión. Su casa era un hervidero de periodistas extranjeros y la televisión danesa, en ese momento en que llegaba yo, recogía sus bártulos una vez culminada su tarea. Como no disponía de tiempo, me pidió que le acompañara a una conferencia en el Liceo francés a la que estaba obligado a ir. Luego le perdí de vista un tiempo, al irse a Estados Unidos. En uno de sus regresos le pedí que me aceptara dedicarle La Culpa. Mi dedicatoria dice así: «Dedico este libro a J. L. L. Araguren, un profesor de Ética para quien la ética no es sólo una cuestión académica, sino práctica.» Luego, él habló de mí, a propósito de este libro, en varias ocasiones, una de ellas en su libro Memorias y esperanzas españolas. 
Nos entendíamos bien. Conocí una etapa de él en la que - $\sin$ dejar de hacer notar cuánto se reservaba - mostraba una capacidad de diversión y de ingenio, y hasta de ternura, que le hacia a uno quererle de inmediato... $Y$, constantemente, su cntrega al juego del gran seductor que fue. Luego, paulatina y discretamente, se fue inhibiendo cada vez más. Hablaba poco, dejaba hablar al interlocutor, escuchaba (sabía escuchar muy bien). Podía soportar, sin aparente tensión, un silencio prolongado, pero era notorio su alivio al intuir que se le iba a dejar solo. No quiso tanto como los demás le quisieron: lo creo sinceramente, pero esto puede no ser más que una conjetura.

Aranguren ha muerto cuando muchos de los que le conocimos hace más de treinta años no podemos considerarnos huérfanos de él. Señal inequívoca de que cumplió sobradamente su cometido, o, para ser más preciso, el cometido que se le hizo cumplir. Porque él era - lo somos todos- quien era, pero también quien se le requería que fuera. Y si así ocurre en todos, en él se hizo más visible que en otros debido a la singular socialidad que le caracterizó y a su presencia emblemática. No era tan libre como nos figuramos que fue, porque se le exigía que fuese, en aquella España sórdida y mediocre, lo que sólo él podía ser: alguien diferente en quien los demás se reconocían. Por eso se le requería insistentemente. Hasta pocos meses antes de su muerte fue el conferenciante (aparte otras instancias: presentaciones de libros, prólogos, mesas redondas, etc.) más solicitado de España. Por eso digo que fue lo que se le pidió, implícita o explícitamente, que estuviera en todas partes, en todo momento: su presencia era algo así como el aval del grupo que le escuchaba.

Se bastó a sí mismo incluso en los meses últimos de su gran desvalimiento, pero al mismo tiempo, hasta un año antes de morir, lo pasaba muy bien con los que consideraba sus amigos, enterándose de todo, escuchando sin apenas hablar él. Al final, su organismo, ya debilitado, se le imponía y le obligaba mentalmente a auscntarse. El verano de 1995, en El Escorial, participó en dos cursos seguidos, es decir, estuvo quince días cn el Euroforum. Se sentaba a mi lado en primera fila. Nunca le había ocurrido antes: se dormía en las conferencias de los demás.

- Te voy a decir una cosa, Carlos. Me he dormido; no sé cuanto tiempo, pero me he dormido.

- Sí, lo vi - le respondía yo.

- Ya sabía yo que no se te pasaría — me decía, sonriendo. Y añadía: ¿Cuánto tiempo habré dormido?

-Una media hora aproximadamente...

- ¿Tanto?

De Aranguren podría decirse que fue la encarnación del hombre interesante. Sociable y retraído, condescendiente, educadísimo (salvo que se le irritara), controlaba bien su distanciamiento. Podías acercarte a él, pero él, por si acaso, establecía una afable barrera no fuera a ser que te acercaras demasiado. Nadie se ha permitido, que yo sepa, una impertinencia en ese sentido, porque nunca dio la luz verde para ello. Por eso, Aranguren se nos ha ido llevándose su secreto consigo. 